FITRAH Jurnal Kajian Ilmu-ilmu Keislaman

Vol. 04 No. 2 Desember 2018

e-ISSN : 2460-2345, p-ISSN: 2442-6997

Web: jurnal.iain-padangsidimpuan.ac.id/index.php/F

\title{
PENGARUH BUDAYA NUSANTARA TERHADAP IMPLEMENTASI NILAI-NILAI ISLAM DI INDONESIA
}

\author{
DOFARI \\ Kepala Sekolah SMP Negeri 1 Suruh Kabupaten Semarang Provinsi Jawa Tengah \\ dan Pemerhati Budaya \\ dofrismpn1@gmail.com
}

\begin{abstract}
This article aims to find out Islamic values that can be easily implemented in Indonesia, convey the peculiarities of the realization of Islamic values in Indonesia, and their influence on the realization of Islamic cultural values. The method used to find out what will be used and distribute several books related to the topic of discussion in this article. This is where the values are very important to enable readers to be based on Islam by knowing the rights of certain customs to be preserved and furthermore not applying traditions that clearly deviate from Islam. The results of the discussion of this article are that the values of Islamic culture in Indonesia can be packaged so attractively when packing Islamic teachings with culture that people are not aware that the values of Islam have become a tradition in their daily lives.
\end{abstract}

Keywords : Islam's as a subtantial; the good culture of archipelago is based on the faith

\begin{abstract}
Abstrak
Artikel ini bertujuan agar pembaca dapat mengetahui bagaimana nilai-nilai Islam yang dapat dengan mudah diimplentasikan di Indonesia, menyampaikan kekhasan perwujudan nilai-nilai Islam di Indonesia, dan pengaruhnya terhadap perwujudan nilai-nilai budaya Islam. Metode yang digunakan adalah kajian pustaka dimana penulis mencoba mengumpulkan beberapa buku terkait dengan topik pembahasan dalam artikel ini. Disinilah nilai penting pembahasan artikel ini agar pembaca sekalian dapat berlandasan Islam dengan memahami betul eksistensi adat istiadat tertentu untuk dilestarikan dan selanjutnya tidak menerapkan tradisi yang jelas menyimpang dari Islam. Hasil pembahasan artikel ini adalah nilai-nilai budaya Islam di Indonesia dapat dikemas dengan sebegitu menariknya sehingga saat mengemas ajaran Islam dengan budaya setempat masyarakat tidak sadar bahwa nlai-nilai Islam telah masuk menjadi tradisi dalam kehidupan sehari-hari mereka.

Kata kunci : Islam sebagai sebuah substans; budaya nusantara yang sesuai akidah
\end{abstract}

\section{PENDAHULUAN}

Indonesia merupakan nama negara kepulauan di Asia Tenggara yang terletak di antara Benua Asia dan Australia. (KBBI Offline). Indonesia pula negara yang masyarakatnya terdiri dari berbagai macam ragamnya, diantaranya yakni kebudayaan, ras, etnis, tradisi hingga agama. Oleh karena itu, Negara Indonesia disebut dengan multikultural. Negara yang memiliki sebutan sebagai 
FITRAH Jurnal Kajian Ilmu-ilmu Keislaman

Vol. 04 No. 2 Desember 2018

multikultural tidaklah dianggap sepele, karena berbagai macam seperti budaya ada di dalamnya. Menurut Siti Chamamah, fenomena pluralitas kultural dan pemahaman agama menjadi menonjol dilihat dari manifestasinya dalam budaya. Memasuki era modern upaya mencermati produk budaya yang telah dihasilkan dan yang mungkin untuk diciptakan signifikan bagi penciptaan masa depan Indonesia baru yang damai dalam persatuan bangsa (dari segi budaya). ${ }^{1}$ Hidup rukun dan saling menghargai (toleransi) sesama makhluk atau sesama warga Negara Indonesia merupakan tujuan yang diharapkan. Sebagai makhluk ciptaan Tuhan pulalah sesama makhluk diharapkan untuk saling menghargai dan hidup rukun berdampingan.

Namun tidak semua hal yang diharapkan atau menjadi tujuan yang diharapkan berjalan secara mulus. Ada kalanya agama dijadikan sebagai bahan perkelahian antara negara satu dengan negara yang lain. Di sebuah acara televisi yang akhir-akhir ini mendapatkan perhatian khusus yang menginformasikan bahwa etnis rohingya terdiskriminasi oleh tentara-tentara atau penegak hukum di negaranya dikarenakan beragama Islam (minoritas) atau permasalahan politik. Dari sini maka sangatlah memprihatinkan bahwa sebuah kepercayaan yang hanya memiliki pengikut minoritas mendapatkan perlakuan yang kurang adil oleh penegak hukum di negara tersebut. Tidak bisa dipungkiri pula bahwa di Negara Indonesia pada masa orda lama pemerintahan Presiden Soekarno pada era 1950-1960 adalah masa dimana etnis Tionghoa sungguh terdiskriminasi dalam wajah yang sangat rasialis. Pengejaran terhadap orang-orang Tionghoa ketika itu merupakan bagian dari pelaksanaan serta pengembangan politik anti Tionghoa pada 1956. Konsep pemikiran dari pemerintah mengenai nasionalisasi perusahaan telah sangat meminggirkan usaha milik orang-orang etnis Tionghoa.

Pada 14 Mei 1959 pemerintah mengeluarkan PP No. 10/1959 yang isinya menetapkan bahwa semua usaha dagang kecil milik orang asing di tingkat desa tidak diberi izin lagi setelah 31 Desember 1959. Peraturan ini terutama ditujukan pada pedagang kecil Tionghoa yang merupakan bagian terbesar orang-orang asing yang melakukan usaha di tingkat desa. Alhasil, semakin mengeraslah perlakuan rasis terhadap orang Tionghoa di Indonesia. ${ }^{2}$

${ }^{1}$ Mufi'ah Anisatun, Harmonisasi Agama dan Kebudayaan di Indonesia (Jakarta Timur: Balai penelitian dan penegmbangan agama jakarta, 2009), hlm. 22.

${ }^{2}$ Ni Nyoman Ayu Nikki Avalokitesvari, “Diskriminasi Etnis Tionghoa di Indonesia Pada Masa Orde Lama dan Orde Baru I Tionghoa Tradisi dan Budaya Tionghoa," Web.blog, 
Banyaknya budaya, etnis, ras serta agama memberikan berbagai dampak dan memberikan warna bagi Negara Indonesia. Seperti diskriminasi yang telah terjadi di berbagai negara tersebut memberikan sebuah arti bahwa kehidupan masyarakat yang terdiri dari minoritas akan mendapatkan perlakuan yang tidak mengenakkan. Lebih-lebih dalam agama, kaum muslim mendapatkan perlakuan tidak adil permasalahan ekonomi yang mengakibatkan tidak sedikit negara mengalami kemiskinan berkelanjutan. Contohnya saja di daerah Jawa Barat, Indramayu.

Melihat permasalahan-permasalahan yang terjadi di Indonesia dapat diambil solusi dalam memecahkan permasalahan tersebut dengan berjihad. Jika kaum Muslim mau mengembangkan konsep jihad. Dengan kata lain, jihad dalam konteks kontemporer harus dipahami secara lebih luas, konstruktif, dan kontekstual untuk mengatasi problem-problem mendasar umat Islam dewasa ini mulai dari kemiskinan, keterbelakangan, kebodohan dan seterusnya. ${ }^{3}$ Dengan saling bertoleransi atau tenggang rasa terhadap sesama manusia (umumnya) dan sesama ummat muslim (khususnya). Dalam al Qur'an Q.S Al Hujurat: 13 pula telah dijelaskan bahwa sesama makhluk haruslah saling mengenal. Makna saling mengenal disini ketika dikaitkan dengan budaya ataupun semacamnya maka saling menghargai. Bahwa menurut penulis semua sama yaitu makhluk ciptaan Allah SWT hanya saja ketaqwaan penulis yang berbeda. "Hai manusia, sesungguhnya Kami menciptakan kamu dari seorang laki-laki dan seorang perempuan dan menjadikan kamu berbangsa - bangsa dan bersuku-suku supaya kamu saling kenalmengenal. Sesungguhnya orang yang paling mulia diantara kamu disisi Allah ialah orang yang paling taqwa diantara kamu. Sesungguhnya Allah Maha Mengetahui lagi Maha Mengenal". Penulis menyusun rumusan masalah pada artikel ini yaitu: 1) Apa saja kekhasan Nilai-nilai Islam di Indonesia dari segi budaya; Apa sajakah pengaruh yang dihasilkan dari nilai-nilai Islam di Indonesia?; Apa penyebab akulturasi budaya Indonesia dengan nilai-nilai Islam?; Masih adakah diskriminasi-diskriminasi yang terjadi di Indonesia?, dengan tujuan untuk: 1) Untuk mengetahui kekhasan Nilai-nilai Islam di Indonesia dari segi buda; 2) Untuk mengetahui pengaruh yang dihasilkan dari nilai-nilai Islam di Indonesia;

Tionghoa.info, 15 Maret 2014, https://www.tionghoa.info/diskriminasi-etnis-tionghoa-di-indonesiapada-masa-orde-lama-dan-orde-baru/.

${ }^{3}$ Deutsche Welle (www.dw.com), “Islam dan Masalah Kemiskinan di 'Dunia Muslim' I DW I 14.12.2016," Web. Blog, DW.COM, diakses 13 September 2018, https://www.dw.com/id/islam-dan-masalah-kemiskinan-di-dunia-muslim/a-36759510. 
FITRAH Jurnal Kajian Ilmu-ilmu Keislaman

Vol. 04 No. 2 Desember 2018

3) Untuk mengetahui penyebab akulturasi budaya Indonesia dengan nilai-nilai Islam; 4) Untuk mengetahui diskriminasi yang terjadi di Indonesia.

\section{METODE PENELITIAN}

Penelitian ini menggunakan metode kualitatif dengan pendekatan deskriptif. Sumber data primer dari penelitian ini adalah literature tentang budaya nusantara yang berkembang di Indonesia baik sebelum masuknya Islam maupun sesudahnya dan literature tentang budaya dan nilai-nilai Islam di Indonesia. Data sekunder diperoleh dari teori-teori dan konsep yang terkait dengan dua pokok persoalan tersebut di atas. Teknik pengumpulan data melalui library riset dan telaah pustaka. Untuk analisa data dengan mengkolaborasikan budaya nusantara terhadap budaya dan nilai-nilai Islam dan selanjutnya diambil kesimpulan.

\section{HASIL PENELITIAN DAN PEMBAHASAN}

\section{Kekhasan nilai-nilai Islam di Indonesia}

Islam masuk ke Indonesia lengkap dengan budayanya. Karena Islam berasal dari Jazirah Arab, maka Islam masuk ke Indonesia tidak terlepas dari budayanya Arab. Kedatangan Islam dengan segala komponen budayanya secara damai lebih menarik simpati sebagian besar masyarakat Indonesia.

Pandangan Nurcholis Majid (1988: 70) dalam bukunya Agus yang berjudul Studi Islam Indonesia mengatakan bahwa daya tarik Islam yang pertama dan utama adalah bersifat psikologis. Islam yang secara radikal bersifat egaliter dan mempunyai semangat keilmuan merupakan konsep revolusioner yang sangat memikat. Sebagaimana dalam Budaya maupun tradisi, para da'i ataupun Walisongo berdakwah menggunakan budaya. Seperti halnya di Pulau Jawa terdapat acara "Nyadran" yang waktu pelaksanaannya dilakukan pada bulan sya'ban. Pada hakikatnya "Nyadran" tidak terdapat pada agama Islam, namun terjadi akulturasi yang dilakukan oleh Walisongo di Jawa menjadikan Islam diterima dengan baik. Salah satu daerah yang masih mempertahankan tradisi ini adalah Boyolali, tepatnya di wilayah Cepogo. Di sini, Sadranan dilangsungkan dengan meriah. Semua masyarakat tanpa terkecuali menyelenggarakan semacam open house dan menjamu siapapun yang bertandang ke rumahnya. Mereka yang hadir tidak hanya datang dari desa setempat. Beberapa diantaranya bahkan datang dari luar daerah menggunakan mobil 
angkutan seperti pick up dan truk, mobil pribadi, hingga kendaraan bermotor. Seperti pesta besar, para peziarah berduyun-duyun datang sembari membawa tenong berisi bermacam makanan. Tradisi Sadranan diawali dengan bergotongroyong membersihkan makam (besik) dan berdoa untuk para leluhur yang telah meninggal, serta sebagai ajang silaturahmi dengan keluarga besar. ${ }^{4}$

Nabi Muhammad SAW pula telah mengajarkan kepada penulis dalam sirahnya bahwasannya beliau pernah melestarikan tradisi jahiliah yang baik, yaitu ritual peribadatan Haji Islam melestarikan banyak manasik Haji yang diwarisi masyarakat Arab dari agama Ibrahim a.s misalnya thawaf, sa'i serta menghilangkan hal-hal yang bertentangan dengan akidah Islam dan nilai-nilai Islam, misalnya ucapan talbiyah: "labaik la syarika laka ila syarika huwa laka, tamlikuhu wala mulk", maksudnya adalah patung-patung. ${ }^{5}$

Adapun wujud akulturasi kebudayaan Indonesia dan kebudayaan Islam antara lain, yaitu: ${ }^{6}$

a. Seni bangunan

Wujud akulturasi dalam seni bangunan dapat dilihat pada masjid, makam serta istana. Adapun ciri dari akulturasi masjid dapat dilihat dari atapnya yang berbentuk tumpang yang memiliki arti atap yang bersusun semakin ke atas semakin kecil dari tingkatan paling atas berbentuk limas. Nilai filosofinya dari bawah adalah aqidah, syariat, thareqat, hakikat, ma'rifat dan taqwa. Contohnya Masjid Agung Demak, Cirebon, Kudus dll.

b. Seni sastra

Seni sastra yang berkembang pada awal periode Islam adalah seni sastra yang berasal dari perpaduan sastra pengaruh Hindu-Budha dan sastra Islam yang banyak mendapat pengaruh Persia. Contohnya yaitu Hikayat, babad, suluk serta primbon.

c. Sistem kalender

\footnotetext{
${ }^{4}$ EH / Islam Indonesia, “Pesan Luhur Tradisi Nyadran: Pada Hakikatnya Semua Manusia Setara," Islam Indonesia an Islam for All (blog), 17 Mei 2017, https://islamindonesia.id/budaya/pesanluhur-tradisi-nyadran-pada-hakikatnya-semua-manusia-setara.htm.

${ }^{5}$ Yūsuf Qaraḍāwī, Kebudayaan Islam, eksklusif atau inklusif (Solo: Era Intermedia, 2001), hlm. 62 https://books.google.co.id/books?id=pKwQAAAACAAJ\&dq=Kebudayaan+Islam+Eksklusif+atau+I nklusif\&hl=en\&sa=X\&ved=0ahUKEwjX1OCt38bfAhUNinAKHQ5DD78Q6AEILTAA.

${ }^{6}$ Agus Hermawan, M.A, Pengantar Studi Islam Indonesia (Kudus: Yayasan Hj. Kartini, 2016), hlm. 14
} 
FITRAH Jurnal Kajian Ilmu-ilmu Keislaman

Vol. 04 No. 2 Desember 2018

Sebelum budaya Islam masuk ke Indonesia, masyarakat Indonesia sudah mengenal Kalender Saka (kalender Hindu) yang dimulai pada tahun 78M. Setelah berkembangnya Islam Sultan Agung dari Mataram menciptakan kalender Jawa dengan menggunakan perhitungan peredaran bulan (qomariah) seperti tahun Hijriyah (Islam).

\section{Pengaruh Nilai-nilai Islam dalam Budaya Nusantara}

Sejak awal perkembangannya, Islam di Indonesia telah menerima akomodasi budaya. Karena Islam sebagai agama memang banyak memberikan norma-norma aturan tentang kehidupan dibandingkan dengan agama-agama lain. Bila dilihat kaitan Islam dengan budaya, paling tidak ada dua hal yang perlu diperjelas: Islam sebagai konsespsi sosial budaya, dan Islam sebagai realitas budaya.

Istilah lain proses akulturasi antara Islam dan Budaya lokal ini kemudian melahirkan apa yang dikenal dengan lokal genius, yaitu kemampuan menyerap sambil mengadakan seleksi dan pengolahan aktif terhadap pengaruh kebudayaan asing, sehingga dapat dicapai suatu ciptaan baru yang unik, yang tidak terdapat di wilayah bangsa yang membawa pengaruh budayanya. Pada sisi lain local genius memiliki karakteristik antara lain: mampu bertahan terhadap budaya luar, mempunyai kemampuan mengakomodasi unsur-unsur budaya luar, mempunyai kemampuan mengintegrasi unsur budaya luar ke dalam budaya asli, memiliki kemampuan mengendalikan dan memberikan arah pada perkembangan budaya selanjutnya.

Norma, aturan, maupun segenap aktivitas masyarakat Indonesia, ajaran Islam telah menjadi pola anutan masyarakat. Dalam konteks inilah Islam sebagai agama sekaligus telah menjadi budaya masyarakat Indonesia. Di sisi lain budaya-budaya lokal yang ada di masyarakat, tidak otomatis hilang dengan kehadiran Islam. Budaya-budaya lokal ini sebagian terus dikembangkan dengan mendapat warna-warna Islam. Perkembangan ini kemudian melahirkan "akulturasi budaya", antara budaya lokal dan Islam.

Budaya-budaya lokal yang kemudian berakulturasi dengan Islam antara lain acara slametan $(3,7,40,100$, dan 1000 hari) di kalangan suku Jawa. Tingkeban (nujuh Hari), dalam bidang seni, juga dijumpai proses akulturasi seperti dalam kesenian wayang di Jawa. Wayang merupakan kesenian tradisional suku Jawa yang berasal dari agama Hindu India. Proses Islamisasi tidak menghapuskan 
kesenian ini, melainkan justru memperkayanya, yaitu memberikan warna nilainilai Islam di dalamnya.tidak hanya dalam bidang seni, tetapi juga di dalam bidang-bidang lain di dalam masyarakat Jawa. Dengan kata lain kedatangan Islam di nusantara dalam taraf-taraf tertentu memberikan andil yang cukup besar dalam pengembangan budaya lokal.

Secara fisik akulturasi budaya yang bersifat material dapat dilihat misalnya: bentuk masjid Agung Banten yang beratap tumpang, berbatu tebal, bertiang saka, dan sebagainya benar-benar menunjukkan ciri-ciri arsitektur lokal. Sementara esensi Islam terletak pada "ruh" fungsi masjidnya. Demikian juga dua jenis pintu gerbang bentar dan paduraksa sebagai ambang masuk masjid di Keraton Kaibon.

Perkembangan selanjutnya sebagaimana diceritakan dalam Babad Banten, Banten kemudian berkembang menjadi sebuah kota. Kraton Banten sendiri dilengkapi dengan struktur-struktur yang mencirikan prototype kraton yang bercorak Islam di Jawa, sebagaimana di Cirebon, Yogyakarta dan Surakarta. Ibukota Kerajaan Banten dan Cirebon kemudian berperan sebagai pusat kegiatan perdagangan internasional dengan ciri-ciri metropolitan di mana penduduk kota tidak hanya terdiri dari penduduk setempat, tetapi juga terdapat perkampungan-perkampunan orang-orang asing, antara lain Pakoja, Pecinan, dan kampung untuk orang Eropa seperti Inggris, Perancis dan sebagainya.

Bidang kerukunan, Islam di daerah Banten pada masa lalu tetap memberikan perlakuan yang sama terhadap umat beragama lain. Para penguasa muslim di Banten misalnya telah memperlihatkan sikap toleransi yang besar kepada penganut agama lain. Misalnya dengan mengizinkan pendirian vihara dan gereja di sekitar pemukiman Cina dan Eropa. Bahkan adanya resimen nonmuslim yang ikut mengawal penguasa Banten. Penghargaan atau perlakuan yang baik tanpa membeda-bedakan latar belakang agama oleh penguasa dan masyarakat Banten terhadap umat beragama lain pada masa itu, juga dapat disaksikan di kawasan-kawasan lain di nusantara, terutama dalam aspek perdagangan. Penguasa Islam di berbagai belahan nusantara telah menjalin hubungan dagang dengan bangsa Cina, India dan lain sebagainya sekalipun di antara mereka berbeda keyakinan.

Aspek akulturasi budaya lokal dengan Islam juga dapat dilihat dalam budaya Sunda adalah dalam bidang seni vokal yang disebut seni beluk. Dalam seni beluk sering dibacakan jenis cerita (wawacan) tentang ketauladanan dan 
FITRAH Jurnal Kajian Ilmu-ilmu Keislaman

Vol. 04 No. 2 Desember 2018

sikap keagamaan yang tinggi dari si tokoh. Seringkali wawacan dari seni beluk ini berasal dari unsur budaya lokal pra-Islam kemudian dipadukan dengan unsur Islam seperti pada wawacan Ugin yang mengisahkan manusia yang memiliki kualitas kepribadian yang tinggi. Seni beluk kini biasa disajikan pada acara-acara selamatan atau tasyakuran, misalnya memperingati kelahiran bayi ke-4 hari (cukuran), upacara selamatan syukuran lainnnya seperti kehamilan ke7 bulan (nujuh bulan atau tingkeban), khitanan, selesai panen padi dan peringatan hari-hari besar nasional.

Akulturasi Islam dengan budaya-budaya lokal nusantara sebagaimana yang terjadi di Jawa didapati juga di daerah-daearah lain di luar Jawa, seperti Sumatera Barat, Aceh, Makasar, Kalimantan, Sumatera Utara, dan daerah-daerah lainnya. Khusus di daerah Sumatera Utara, proses akulturasi ini antara lain dapat dilihat dalam acara-acara seperti upah-upah, tepung tawar, dan marpangir. Contoh-contoh Budaya Nusantara yang mengandung nilai-nilai Islam

Tepung tawar, biasa dilakukan dengan menghambur-hambur beras kepada orang yang ditepung tawari. Adapun upah-upah, juga merupakan upacara menolak kesialan. Biasanya dilakukan terhadap orang yang sakit agar spiritualnya (roh) kembali ke jasadnya. Yaitu dengan memasak ayam kemudian diletakkan di piring lalu dibawa mengitari orang yang akan diupah-upahi, kemudian disuapkan kepada orang tersebut. Tujuannya ialah mengembalikan semangat pada orang sakit itu.

Kebiasaan sungkeman berasal dari pulau Jawa yang umumnya dilakukan pada saat Hari Raya dan pada upacara pernikahan, tetapi kadang kala dilakukan juga setiap kali bertemu. Dilakukan dengan cara sujud kepada orang tua atau orang yang dianggap sepuh (Jawa, tua atau dituakan). Adat ini mengandung unsur sujud dan rukuk kepada selain Allah, yang tentunya dilarang dalam Islam.

Tabot atau Tabuik, adalah upacara tradisional masyarakat Bengkulu untuk mengenang kisah kepahlawanan dan kematian cucu Nabi Muhammad, Hasan dan Husein bin Ali bin Abi Thalib dalam peperangan dengan pasukan Ubaidillah bin Zaid di Padang Karbala, Irak pada tanggal 10 Muharam 61 Hijriah (681 M). Perayaan di Bengkulu pertama kali dilaksanakan oleh Syaikh Burhanuddin yang dikenal sebagai Imam Senggolo pada tahun 1685. Syaih Burhanuddin (Imam Senggolo) menikah dengan wanita Bengkulu kemudian 
anak mereka, cucu mereka dan keturunan mereka disebut sebagai keluarga Tabot. Upacara ini dilaksanakan dari 1 sampai 10 Muharram (berdasar kalendar Islam) setiap tahun. Pada awalnya, inti upacara Tabot ialah untuk mengenang upaya pemimpin Syi'ah dan kaumnya mengumpulkan potongan tubuh Husein, mengarak dan memakamkannya di Padang Karbala. Istilah Tabot berasal dari kata Arab, "tabut", yang secara harfiah berarti kotak kayu atau peti. Tidak ada catatan tertulis sejak kapan upacara Tabot mulai dikenal di Bengkulu. Namun, diduga kuat tradisi yang berangkat dari upacara berkabung para penganut paham Syi'ah ini dibawa oleh para tukang yang membangun Benteng Marlborought (1718-1719) di Bengkulu. Para tukang bangunan tersebut, didatangkan oleh Inggris dari Madras dan Bengali di bagian selatan India yang kebetulan merupakan penganut Islam Syi'ah. Selanjutnya Tingkepan, babaran, pitonan dan pacangan merupakan kebiasaan masyarakat desa di Jawa Timur, seperti halnya di Jawa Tengah, memiliki ikatan yang berdasarkan persahabatan dan teritorial.

\section{Penyebab Akulturasi Budaya Nusantara dengan Nilai-nilai Islam}

Akibat dari kemunduran situasi politik. adipati-adipati pesisir yang melakukan perdagangan dengan pedagang muslim, dan akhirnya mereka menjadi penerima Agama Islam. Situasi politik seperti itu mempengaruhi masuknya Islam ke nusantara lebih mudah. Karena kekacauan politik, mengakibatkan kacauan pada budaya dan tradisi masyarakat. Kedua, kekacauan budaya ini digunakan oleh mubaligh-mubaligh dan pedagang muslim yang sudah mukim untuk menjalin hubungan yang lebih dekat yaitu melalui perkawinan. Akibatnya pada awal Islam di nusantara sudah ada keturunan Arab atau India. Misalnya di Surakarta terdapat perkampungan Arab, tepatnya di para Kliwon (kampung Arab).

Islam di Nusantara, terbukti budaya danajaran Islam mulai berkembang. Hal ini tidak bisa terlepas dari peran mubaligh-mubaligh dan peran Walisongo di Jawa. Bukti bahwa ajaran Islam sudah dikerjakan masyarakat nusantara. Di kota-kota besar dan kecil yang sudah Islam, terdapat bangunan-banguna masjid yang digunakan untuk berjamaah. Hal itu merupakan bukti budaya yang telah berkembang di nusantara.

Kesejahteraan dan kedamaian tersebut dimantapkan secara sosio-religius dengan ikatan perkawinan yang membuat tradisi Islam Timur Tengah menyatu 
FITRAH Jurnal Kajian Ilmu-ilmu Keislaman

Vol. 04 No. 2 Desember 2018

dengan tradisi nusantara, seperti di Jawa. Akulturasi budaya ini tidak mungkin terelakkan setelah terbentuknya keluarga muslim yang merupakan embrio komunitas muslim dan selanjutnya memainkan peranan yang sangat besar dalam penyebaran Islam. Akulturasi budaya ini semakin menemukan momentumnya saat para pedagang ini menyunting keluarga elit pemerintahan atau keluarga kerajaan yang berimplikasi pada pewarisan "kekuatan politik" di kemudian hari.

Tiga daerah asal para pedagang tersebut dari Arab (Mekah-Mesir), Gujarat (India), dan Persia (Iran) tersebut menambah varian akulturasi budaya Islam nusantara semakin plural. Hal ini bisa dirujuk adanya gelar sultan al-Malik bagi raja Kesultanan Samudra Pasai. Gelar ini mirip dengan gelar sultan-sultan Mesir yang memegang madzhab syafi'iah, gaya batu nisan menunjukkan pengaruh budaya India, sedangkan tradisi syuroan menunjukkan pengaruh budaya Iran atau Persia yang syi'ah. Budaya Islam nusantara memiliki warna pelangi. Di saat para pedagang dan kemunitas muslim sedang hangat memberikan sapaan sosiologis terhadap komunitas Nusantara dan mendapatkan respon yang cukup besar sehingga memiliki dampak politik yang semakin kuat, di Jawa Kerajaan Majapahit pada abad ke-14 mengalami kemunduran dengan ditandai candra sangkala, sirna ilang kertaning bumi (1400/1478 M) yang selanjutnya runtuh karena perang saudara. Setelah Majapahit runtuh daerahdaerah pantai seperti Tuban, Gresik, Panarukan, Demak, Pati, Yuwana, Jepara, dan Kudus mendeklarasikan kemerdekaannya kemudian semakin bertambah kokoh dan makmur.

Basis pesantren daerah-daerah pesisir ini kemudian mendaulat Raden Fatah yang diakui sebagai putra keturunan Raja Majapahit menjadi sultan kesultanan Demak yang pertama. Demak sebagai "simbol kekuatan politik" hasil akulturasi budaya lokal dan Islam menunjukkan dari perkawinan antara pedagang Muslim dengan masyarakat lokal sekaligus melanjutkan "warisan" Kerajaan Majapahit yang dibangun di atas tradisi budaya Hindu-Budhis yang kuat sehingga peradaban yang berkembang terasa bau mistik panteistiknya dan mendapat tempat yang penting dalam kehidupan keagamaan Islam Jawa sejak abad ke 15 dan 16. Hal ini bisa ditemukan dalam karya sastra Jawa yang menunjukkan dimensi spiritual mistik yang kuat.

Islam yang telah berinteraksi dengan budaya Arab, India, dan Persia dimatangkan kembali dengan budaya nusantara yang animis-dinamis dan 
Hindu-Budhis. Jika ditarik pada wilayah lokal Jawa masyarakat muslim Jawa menjadi cukup mengakar dengan budaya Jawa Islam yang memiliki kemampuan yang kenyal (elastis) terhadap pengaruh luar sekaligus masyarakat yang mampu mengkreasi berbagai budaya lama dalam bentuk baru yang labih halus dan berkualitas.

Asimilasi budaya dan akomodasi pada akhirnya menghasilkan berbagai varian keislaman yang disebut dengan Islam lokal yang berbeda dengan Islam dalam great tradition. Fenomena demikian bagi sebagian pengamat memandangnya sebagai penyimpangan terhadap kemurnian Islam dan dianggapnya sebagai Islam sinkretis. Meskipun demikian, banyak peneliti yang memberikan apresiasi positif dengan menganggap bahwa setiap bentuk artikulasi Islam di suatu wilayah akan berbeda dengan artikulasi Islam di wilayah lain.

Untuk itu gejala ini merupakan bentuk kreasi umat dalam memahami dan menerjemahkan Islam sesuai dengan budaya mereka sendiri sekaligus akan memberikan kontribusi untuk memperkaya mozaik budaya Islam. Proses penerjemahan ajaran Islam dalam budaya lokal memiliki ragam varian seperti ritual suluk bagi masyarakat Minangkabau yang mengikuti tarekat Naqsyabandiyyah, sekaten di Jogjakarta, lebaran di Indonesia, dan lain sebagainya.

Persinggungan Islam di Jawa dengan budaya kejawen dan lingkungan budaya istana (Majapahit) mengolah unsur-unsur hinduisme dan budaya pedesaan (wong cilik) yang tetap hidup meskipun lambat laun penyebaran dan tradisi keislaman semakin jelas hasilnya. Budaya Islam masih sulit diterima dan menembus lingkungan budaya Jawa istana yang telah canggih dan halus itu.

Penolakan raja Majapahit terhadap agama baru, membuat Islam tidak mudah masuk lingkungan istana. Untuk itu para dai agama Islam lebih menekankan kegiatan dakwahnya dalam lingkungan masyarakat pedesaan, terutama daerah pesisiran dan diterima secara penuh oleh masyarakat pedesaan sebagai peningkatan budaya intelektual mereka, dalam kerja sosial dan dakwahnya, para Wali Songo juga merespon cukup kuat terhadap sikap akomodatif terhadap budaya tersebut. Di antara mereka yang sering disebut adalah Sunan Kalijaga.

Demoralisasi yang terjadi di Jawa karena perang saudara tersebut, kalangan muslim, lewat beberapa tokohnya seperti Sunan Kalijaga mampu 
FITRAH Jurnal Kajian Ilmu-ilmu Keislaman

Vol. 04 No. 2 Desember 2018

menampilkan sosok yang serba damai dan rukun. Jawa sebagai negeri pertanian yang amat produktif, damai, dan tenang. Sikap akomodatif yang dilakukan oleh para dai ini melahirkan kedamaian dan pada gilirannya menumbuhkan simpati bagi masyarakat Jawa. Selain karena proses akulturasi budaya akomodatif tersebut, menurut Ibnu Kholdun, juga karena kondisi geografis seperti kesuburan dan iklim atau cuaca yang sejuk dan nyaman yang berpengaruh juga terhadap perilaku penduduknya. Pandangan serupa juga dikemukakan oleh Syahrastani, dalam al-Milal wa al-Nihal yang menyebutkan ada pengaruh posisi atau letak geografis dan suku bangsa terhadap pembentukan watak atau karakter penduduknya.

Faktor fisiologis mempengaruhi watak psikologis dan sosialnya. Begitu juga letak geografis, tingkat kesuburan, dan kesejukan pulau Jawa akan mempengaruhi seseorang dalam berperilaku dan bersikap. Siapapun yang ingin sukses di Jawa ia harus memperhatikan karakteristik ini sehingga strategi dan pendekatan yang digunakan bisa berjalan dengan baik dan efektif.

Akulturasi dan adaptasi keislaman orang Jawa yang didominasi keyakinan campuran mistik konsep Hindu-Budha disebut kejawen atau juga dinamakan agama Jawi. Sementara penyebaran Islam melalui pondok pesantren khususnya di daerah pesisir utara belum mampu menghilangkan semua unsur mistik sehingga tradisi Islam kejawen tersebut masih bertahan. Pemeluk kejawen dalam melakukan berbagai aktivitasnya dipengaruhi oleh keyakinan, konsep pandangan, dan nilai-nilai budaya yang berbeda dengan para santri yang mengenyam pendidikan Islam lebih murni.

\section{Daerah yang masih terjadi Diskriminasi.}

Indonesia bukanlah negara yang ber-kebhineka-an yang terdiri dari perbedaan masyarakat dalam menganut agama, perbedaan suku, golongan, dan juga antar golongan. Dalam bahasa lain bahwa penulis ketahui Indonesia merupakan negara multikultur. Yang penulis ketahui bahwa sangat beragam isi negara ini. Tidak bisa dipungkiri pula bahwa negara Indonesia negara multikultur, namun dapat penulis ketahui meskipun berbeda-beda dalam banyak hal, namun tetap dapat saling toleransi. Seperti yang pernah penulis dengar pula saat di sekolah dasar yakni meskipun berbeda-beda tetapi tetap satu jua semboyan yang terdapat pada Bhineka Tunggal Ika. 
Indonesia yang hingga kini mendapatkan perlakuan kurang adil, sebut saja di Yogyakarta terdapat ras China yang mendapatkan diskriminasi persoalan ras China tidak boleh mempunyai Tanah, dikutip dari BBC Indonesia. Bukan Yogyakarta saja, di daerah Jakarta pun juga masih terjadi sesuai dengan tutur Ahmad Fuad, "Penulis melihat ada sebuah keganjilan pasca orde baru, salah satu sisi merasakan demokrasi, ekspresi, berserikat. Tetapi di sisi lain meningkatnya diskriminasi terhadap orang-orang minoritas," kata Ahmad Fuad Fanani, Peneliti Maarif Institute dalam diskusi Negara, Agama, dan Problem Perlindungan Hak-hak Minoritas, di Kantor Pengurus Pusat (PP) Muhammadiyah, Menteng, Jakarta Pusat, Rabu (19/12/2012), dikutip Sindonews.com, Tidak bisa dipungkiri pula, Indonesia masih tinggi angka diskriminasi yang terjadi pada kaum-kaum minoritas.

\section{PENUTUP}

Islam masuk Indonesia lengkap dengan budayanya. Karena Islam berasal dari jazirah Arab, maka Islam masuk ke Indonesia tidak terlepas dari budaya Arabnya. Kedatangan Islam dengan segala komponen budayanya di Indonesia secara damai telah menarik simpatik sebagian besar masyarakat Indonesia. Hal ini tidak terlepas dari situasi politik yang tengah terjadi saat itu. Perkembangan dakwah Islam di Indonesia, para da'i mendakwahkan ajaran Islam melalui bahasa budaya, sebagaimana dilakukan oleh Wali Songo di tanah Jawa. Karena kehebatan para wali Allah SWT itu dalam mengemas ajaran Islam dengan bahasa budaya setempat sehingga masyarakat tidak sadar bahwa nilai-nilai Islam telah masuk dan menjadi tradisi dalam kehidupan sehari-hari mereka

Penulis mengajukan rekomendasi bagi pembaca Penulis ketahui bahwa nilai-nilai Islam masuk ke Indonesia melalui beberapa jalur dan akulurasi budaya Islam dan lokal menghasilkan perpaduan nilai-nilai yang sempurna. Maka dari itu penulis juga harus tetap menjaga nilai-nilai itu agar tetap utuh dan tidak luntur oleh zaman. Bagi masyarakat harus bisa memilah mana budaya yang bertentanga dengan Islam dan mana yang tidak. Budaya yang bertentangan penulis tinggalkan dan yang tidak bertentanangan penulis laksanakan. Dari proses akulturasi budaya yang menghasilkan pengaruh serta nilai-nilai yang khas di Indonesia, sebaiknya penulis ajarkan juga kepada generasi selanjutnya agar mereka menegtahui dan melenyapkan nilai-nilai itu. 
FITRAH Jurnal Kajian Ilmu-ilmu Keislaman

Vol. 04 No. 2 Desember 2018

\section{DAFTAR PUSTAKA}

Anisatun, Mufi'ah. Harmonisasi Agama dan Kebudayaan di Indonesia. Jakarta Timur: Balai penelitian dan penegmbangan agama jakarta, 2009.

Avalokitesvari, Ni Nyoman Ayu Nikki. “Diskriminasi Etnis Tionghoa di Indonesia Pada Masa Orde Lama dan Orde Baru | Tionghoa Tradisi dan Budaya Tionghoa." Web.blog. Tionghoa.info, 15 Maret 2014. https://www.tionghoa.info/diskriminasi-etnis-tionghoa-di-indonesiapada-masa-orde-lama-dan-orde-baru/.

EH / Islam Indonesia. "Pesan Luhur Tradisi Nyadran: Pada Hakikatnya Semua Manusia Setara." Islam Indonesia an Islam for All (blog), 17 Mei 2017. https://islamindonesia.id/budaya/pesan-luhur-tradisi-nyadran-padahakikatnya-semua-manusia-setara.htm.

Hermawan, M.A, Agus. Pengantar Studi Islam Indonesia. Kudus: Yayasan Hj. Kartini, 2016.

Qaraḍāwī, Yūsuf. Kebudayaan Islam, eksklusif atau inklusif. Solo: Era Intermedia, 2001.

https://books.google.co.id/books?id=pKwQAAAACAAJ\&dq=Kebudayaa n+Islam+Eksklusif+atau+Inklusif\&hl=en\&sa=X\&ved=0ahUKEwjX1OCt38b fAhUNinAKHQ5DD78Q6AEILTAA.

Welle (www.dw.com), Deutsche. "Islam dan Masalah Kemiskinan di 'Dunia Muslim' I DW I 14.12.2016.” Web. Blog. DW.COM. Diakses 13 September 2018. https://www.dw.com/id/islam-dan-masalah-kemiskinan-di-duniamuslim/a-36759510. 